\title{
The ketone body $\beta$-hydroxybutyric acid influences agouti-related peptide expression via AMP-activated protein kinase in hypothalamic GT1-7 cells
}

\author{
Thomas Laeger ${ }^{1}$, Ralf Pöhland ${ }^{2}$, Cornelia C Metges ${ }^{1}$ and Björn Kuhla ${ }^{1}$ \\ ${ }^{1}$ Research Unit Nutritional Physiology "Oskar Kellner" and ${ }^{2}$ Research Unit Reproductive Biology, Leibniz Institute for Farm Animal Biology (FBN), \\ Wilhelm-Stahl-Allee 2, 18196 Dummerstorf, Germany \\ (Correspondence should be addressed to B Kuhla; Email: b.kuhla@fbn-dummerstorf.de)
}

\begin{abstract}
$\beta$-Hydroxybutyric acid (BHBA) acts in the brain to influence feeding behaviour, but the underlying molecular mechanisms are unclear. GT1-7 hypothalamic cells expressing orexigenic agouti-related peptide (AGRP) were used to study the AMPactivated protein kinase (AMPK) pathway known to integrate dietary and hormonal signals for food intake regulation. In a $25 \mathrm{mM}$ glucose culture medium, BHBA increased intracellular calcium concentrations and the expression of monocarboxylate transporter 1 (MCT1 (SLC16A1)). Phosphorylation of AMPK- $\alpha$ (PRKAA1 and PRKAA2) at $\mathrm{Thr}^{172}$ was diminished after $2 \mathrm{~h}$ but increased after $4 \mathrm{~h}$. Its downstream target, the mammalian target of rapamycin, was increasingly phosphorylated on $\operatorname{Ser}^{2448}$ after $2 \mathrm{~h}$ but not changed after $4 \mathrm{~h}$ of BHBA treatment. After $4 \mathrm{~h}$, BHBA
\end{abstract}

treatment also increased Agrp mRNA expression. This increase was prevented by preincubation with the AMPK inhibitor Compound C. The inhibition of MCT1 activity by p-hydroxymercuribenzoate suppressed BHBA-stimulated AMPK phosphorylation but did not prevent BHBA-induced Agrp mRNA expression. This finding demonstrates that BHBA triggers the AMPK pathway resulting in orexigenic signalling under $25 \mathrm{mM}$ glucose culture conditions. Under conditions of $5.5 \mathrm{mM}$ glucose, however, BHBA marginally increased intracellular calcium but significantly decreased AMPK phosphorylation and Agrp mRNA expression, demonstrating that under physiological conditions BHBA reduces central orexigenic signalling.

Journal of Endocrinology (2012) 213, 193-203

\section{Introduction}

As an important intermediate of amino and fatty acid catabolism, D- $\beta$-hydroxybutyric acid (BHBA), like glucose, can be used by the brain to provide energy particularly for suckling newborns (Hawkins et al. 1971). BHBA may access the brain by crossing the blood-brain barrier as well as entering hypothalamic neurons via the monocarboxylate transporter 1 (MCT1 (SLC16A1); Tildon \& Roeder 1988, Ainscow et al. 2002, Morris \& Felmlee 2008).

The impact of BHBA on satiety has recently been summarised (Laeger et al. 2010). In contrast to diabetic hyperketonaemia, which is usually associated with hyperphagia (Goodman 1987, Friedman \& Ramirez 1994, Toyonaga et al. 2002), i.c.v. application of BHBA rather diminishes food intake (Sakata et al. 1982, Arase et al. 1988). Based on these findings, it has recently been suggested that BHBA may also be involved in the regulation of hypophagic responses (Laeger et al. 2010); however, the underlying molecular mechanisms are still not resolved.

In the hypothalamus, one of the central regulators of food intake and energy homeostasis, the AMP-activated protein kinase (AMPK (PRKAA2)) pathway is activated in response to an increase in the AMP:ATP ratio and integrates extracellular hormonal and nutrient signals (Hardie et al. 1999, Minokoshi et al. 2004, Xue \& Kahn 2006, Kola 2008). Activation of AMPK (phosphorylation of $\mathrm{Thr}^{172}$ at the $\alpha$ subunit) leads to an increased expression of orexigenic neuropeptides (NP) such as NPY and agouti-related peptide (AGRP) and a decreased expression of anorexigenic NP such as pro-opiomelanocortin (POMC; Kola 2008). The inhibition of AMPK by Compound C (Cpd C) prevents these expression changes (Iwasaki et al. 2007, Shimizu et al. 2008).

Incubation of hippocampal neurons with BHBA but without glucose maintains the cellular ATP level (Arakawa et al. 1991), suggesting that BHBA may modulate hypothalamic AMPK activity. Upstream kinases of AMPK are the tumour suppressor LKB1 (STK11) kinase and the $\mathrm{Ca}^{2+}$, calmodulin-dependent protein kinase I (CAMKI (CAMK1)), the latter dependent on intracellular $\mathrm{Ca}^{2+}$ release (Hawley et al. 2003, Hurley et al. 2005, Witters et al. 2006). Once phosphorylated at $\mathrm{Thr}^{172}$, AMPK may inhibit its downstream target mammalian target of rapamycin (mTOR), which in turn integrates amino acid and insulin signalling and thereby 
regulating transcriptional activity (Bolster et al. 2002, Kimura et al. 2003).

The aim of this study was to investigate the effect of BHBA on hypothalamic orexigenic signalling. GT1-7 cells have been successively used to investigate orexigenic signalling (Yang et al. 2005, Li et al. 2006, Morrison et al. 2007, Hayes et al. 2011). Using this model, we could show that BHBA increases intracellular $\mathrm{Ca}^{2+}$ release and modulates the phosphorylation of AMPK and mTOR in a time- and glucose-dependent manner. Changes in AMPK phosphorylation were at least in part mediated by MCT1 and accompanied with an altered Agrp mRNA expression.

\section{Materials and Methods}

\section{Cell culture of hypothalamic GT1-7 cells}

Murine-immortalised GT1-7 hypothalamic cells were kindly provided by Dr Franz Schäfer, University of Heidelberg, Germany. GT1-7 cells were developed by Mellon et al. (1990) from a tumour obtained from a transgenic mouse in which the gonadotrophin-releasing hormone (GNRH (GNRH1)) promoter sequence drives the expression of SV40 $\mathrm{T}$ antigen (Tg(Lhb-TAg)\#Plm) but does not alter the expression of Agrp. GT1-7 cells were seeded on $6 \mathrm{~cm}$ culture plates and maintained in DMEM (with $4.5 \mathrm{~g} / 1(25 \mathrm{mM})$ or $1 \mathrm{~g} / 1$ $(5.5 \mathrm{mM})$ glucose, L-glutamine, sodium pyruvate and $3.7 \mathrm{~g} /$ $1 \mathrm{NaHCO}_{3}$ ) supplemented with 10\% (v/v) FCS and 1\% (v/v) penicillin-streptomycin solution (PAN Biotech $\mathrm{GmbH}$, Aidenbach, Germany) at $37^{\circ} \mathrm{C}$ in $5 \% \mathrm{CO}_{2}$ atmosphere. The culture medium was changed twice a week and cultures were passaged at $80 \%$ confluence after trypsinisation $(0 \cdot 05 \%$, $\mathrm{w} / \mathrm{v})$. Changes in cell morphology and growing conditions were carefully monitored using an inverted microscope. To reduce mitogenic effects, GT1-7 cells were precultured in $0 \cdot 1 \%(\mathrm{v} / \mathrm{v}) \mathrm{FCS} / \mathrm{DMEM}$ for $24 \mathrm{~h}$. BHBA was added to the culture medium either alone or $5 \mathrm{~min}$ after preincubation with the MCT1 inhibitor $p$-hydroxymercuribenzoate (pHMB; Sigma-Aldrich; dissolved to $0.5 \mathrm{mM}$ stock solution in $\mathrm{H}_{2} \mathrm{O}$ ) to block the transfer (Deuticke 1982) or the AMPK inhibitor Cpd C (Zhou et al. 2001; Cpd C; Merck; dissolved to $10 \mathrm{mM}$ in dimethyly sulfoxide (DMSO)) in concentrations and times as indicated. Control incubations were performed using $\mathrm{H}_{2} \mathrm{O}$ or DMSO as described earlier. The dilution of the cell culture medium by $\mathrm{pHMB}$ was not higher than 2:1000 and by Cpd $\mathrm{C}$ was not higher than 1:1000.

\section{Western immunoblot analysis}

The cell culture medium was withdrawn and GT1-7 cells were solubilised in $80 \mu \mathrm{l}$ lysis buffer containing $50 \mathrm{mM}$ Tris (pH 7·8), 1 mM EDTA (Pharmacia Biotech), $10 \mathrm{mM} \mathrm{NaF}$ (Fisher Scientific, Schwerte, Germany), 1\% (v/v) Igepal CA-630 (Sigma-Aldrich), $0 \cdot 1 \%(\mathrm{v} / \mathrm{v})$ Triton X-100 (Pharmacia Biotech), 0.5\% (v/v) deoxycholic acid (DOC; Sigma), $0 \cdot 1 \%(\mathrm{w} / \mathrm{v})$ sodium dodecyl sulfate (SDS; USB
Corporation, Cleveland, OH, USA) and Roche PhosphoStop tablets (one tablet $/ 10 \mathrm{ml}$ buffer; Roche) on ice. After centrifugation $\left(4^{\circ} \mathrm{C}, 10 \mathrm{~min}, 15700 \mathrm{~g}\right.$ ), the supernatant was collected and the protein content was quantified using CBQCA Protein Quantitation Kit C-6667 (Molecular Probes, Inc., Eugene, OR, USA) according to the manufacturer's protocol. For SDS gel electrophoresis, $25 \mu \mathrm{g}$ sample solutions were diluted to the same amount with SDS sample buffer containing $62 \cdot 5 \mathrm{mM}$ Tris (pH 6.8), 2\% (w/v) SDS, $10 \%$ $(\mathrm{v} / \mathrm{v})$ glycerol, $5 \%(\mathrm{v} / \mathrm{v}) 2$-mercaptoethanol and $0 \cdot 001 \%(\mathrm{v} / \mathrm{v})$ bromophenol blue. The samples were boiled for $5 \mathrm{~min}$ and electrophoresed through a $12 \%(\mathrm{w} / \mathrm{w})$ SDS polyacrylamide gel. Proteins were then transferred to nitrocellulose membranes. Membranes were blocked with 3\% (w/v) BSA in TBST buffer $(20 \mathrm{mM}$ Tris/ $\mathrm{HCl}, 0 \cdot 9 \%$ (w/v) $\mathrm{NaCl}, 0 \cdot 05 \%$ (v/v) Tween-20; $\mathrm{pH} \mathrm{7 \cdot 6)}$ and incubated with the primary rabbit antibodies against AMPK- $\alpha$, phospho-AMPK- $\alpha$ $\mathrm{Thr}^{172}$, mTOR, phospho-mTOR Ser ${ }^{2448}$ (each from Cell Signaling Technology, Inc., Danvers, MA, USA), chickenanti-MCT1 (Millipore Corporation, Billerica, MA, USA) or after stripping and re-probing with mouse-anti- $\beta$-tubulin antibody (Covance, Inc., Emeryville, CA, USA) at $4{ }^{\circ} \mathrm{C}$ for $12 \mathrm{~h}$ (each 1:1000 dilution). Membranes were then washed with TBST, incubated with the corresponding HRPconjugated anti-mouse, anti-rabbit or anti-chicken IgG (each 1:3000, $60 \mathrm{~min}$ at room temperature). After washing three times with TBST, the membranes were transferred to ECL solution (Pierce ECL Western Blotting Substrate; Thermo Scientific, Rockford, IL, USA) for $1 \mathrm{~min}$ and exposed to Clear Blue X-Ray Film (CL-XPosure Film; Thermo Scientific) for 0.5-2 min. Bands were scanned and quantified using Image $1.42 \mathrm{q}$ (Wayne Rasband, National Institutes of Health, Bethesda, MD, USA). The level of phosphorylation of an assayed enzyme was calculated relative to the total amount of this enzyme. MCT1 levels were assessed relative to $\beta$-tubulin levels.

\section{$R N A$ extraction, reverse transcriptase and quantitative real-time $P C R$ analysis}

Total RNA of GT1-7 cells was extracted using a NucleoSpin RNA XS kit (Macherey-Nagel GmbH, Düren, Germany), subsequently quantified by measuring the absorbance at 260 and $280 \mathrm{~nm}$ (NanoPhotometer; Implen, Munich, Germany) and stored at $-80^{\circ} \mathrm{C}$ until analysis. The quality of extracted RNA was judged by northern analysis and inspection of the $28 S$ and $18 S$ rRNA bands. The extracted RNA $(0.5 \mu \mathrm{g})$ was subjected to a RT-PCR using Transcriptor High Fidelity cDNA Synthesis Kit (Roche) with anchored oligo $(\mathrm{dT})_{18}$ primer $(2.5 \mu \mathrm{M})$ at $65^{\circ} \mathrm{C}$ for $10 \mathrm{~min}$ to ensure denaturation of RNA secondary structures. Subsequently, Protector RNase Inhibitor $(20 \mathrm{U}, 1 \mathrm{mM})$, deoxynucleotide $\operatorname{mix}(1 \mathrm{mM})$, dithiothreitol $(5 \mathrm{mM})$ and Transcriptor High Fidelity Reverse Transcriptase $(10 \mathrm{U})$ were added and RT was performed using $\mathrm{MgCl}_{2}(8 \mathrm{mM})$ for $30 \mathrm{~min}$ at $50{ }^{\circ} \mathrm{C}$. The transcriptase was subsequently inactivated by heating at $85^{\circ} \mathrm{C}$ for $5 \mathrm{~min}$. 
The expression level for Agrp was determined relative to glyceraldehyde-3-phosphate dehydrogenase (Gapdh) using the following primers: Agrp, sense 5'-TGA CTG CAA TGT TGC TGA GTT GTG- $3^{\prime}$ and anti-sense $5^{\prime}$-TAG GTG CGA CTA CAG AGG TTC GTG-3' (391 bp fragment); Gapdh, sense $5^{\prime}$-AAC TTT GGC ATT GTG GAA GG- $3^{\prime}$ and antisense $5^{\prime}$-ACA CAT TGG GGG TAG GAA CA-3' (223 bp). Primer searches were carried out against previously identified genes using the Basic Local Alignment Search Tool (BLAST) program (http://www.ncbi.nlm.nih.gov/BLAST/) of the GenBank database (National Center for Biotechnology Information, Washington, DC, USA).

For quantification of Agrp and Gapdh transcript levels, realtime PCR was performed using LightCycler FastStart DNA Master ${ }^{\text {plus }}$ SYBR Green I (Roche) under each optimised condition of annealing at $59^{\circ} \mathrm{C}$, according to the manufacturer's protocol. An aliquot of the PCR product was electrophoresed on a $3 \%(\mathrm{w} / \mathrm{v})$ agarose gel and visualised by ethidium bromide staining to confirm purity and size. To analyse the relative changes in gene expression, the $2^{-\Delta \Delta C_{\mathrm{T}}}$ method was used (Livak \& Schmittgen 2001).

\section{$\mathrm{Ca}^{2+}$ imaging and confocal laser scanning microscopy}

Hypothalamic GT1-7 cells were washed with PBS $\left(50 \mathrm{mM} \mathrm{Na} 2 \mathrm{HPO}_{4}, 0.85 \%\right.$ (w/v) NaCl, $0 \cdot 25$ (w/v) KCl; $\mathrm{pH} 7 \cdot 4)$, incubated with the cell-permeant acetoxymethyl ester Fluo-4 at $3 \mu \mathrm{M}$ and $0.07 \%$ (v/v) Pluronic F-127 (Molecular Probes) in 0.1\% (v/v) FCS/DMEM for $45 \mathrm{~min}$ at $37^{\circ} \mathrm{C}$ in $5 \% \mathrm{CO}_{2}$ atmosphere. After loading the GT1-7 cells were washed with PBS and incubated in indicator-free $0 \cdot 1 \%$ (v/v) FCS/DMEM for further $30 \mathrm{~min}$. Afterwards, GT1-7 cells were incubated in a Microscope Incubator (XL-3-LSM; Pecon, Erbach, Germany) at $37^{\circ} \mathrm{C}$ in $5 \% \mathrm{CO}_{2}$ atmosphere and analysed for fluorescence at a confocal laser scanning microscope (LSM 5 Pascal, Axiovert 200M, Zeiss, Jena, Germany) and Zen 2007 Software (Carl Zeiss) before and after BHBA stimulation in concentrations as indicated. For the measurement of green fluorescence, $488 \mathrm{~nm}$ line of Argon laser $(30 \mathrm{~mW})$ and a $505-530 \mathrm{~nm}$ narrowband filter were used. Stacks of images (ten images per second, $256 \times 256$ pixel) were recorded using a $20 \times$ lens and the provided software. Analysis 3.2 (SIS, Münster, Germany) was used to create regions of interest (ROIs) exactly enclosing the GT1-7 cells and to measure the mean intensity in ROIs according to Pöhland et al. (2008).

\section{Statistical analysis}

Data were statistically analysed by Systat version 10 using the F-test (see figure legends) and a two-way (BHBA concentration and incubation time) ANOVA (main effects: BHBA treatment and incubation time) followed by comparison of means using the Tukey's test. A statistically significant difference was considered when $P \leq 0 \cdot 05$.

\section{Results}

Effect of BHBA on AMPK and $m$ TOR signalling in hypothalamic GT1-7 cells

Based on the previous studies showing that neurons incubated for $2 \mathrm{~h}$ with BHBA revealed increased ATP levels (Arakawa et al. 1991), we first cultured hypothalamic GT1-7 cells in $25 \mathrm{mM}$ glucose-containing medium as described earlier (Li et al. 2006, Coyral-Castel et al. 2008, Hayes et al. 2011) and investigated whether BHBA modulates AMPK phosphorylation. Incubation with $1 \cdot 5,3$ and $6 \mathrm{mM}$ BHBA for 2 and $4 \mathrm{~h}$ revealed that treatment with $6 \mathrm{mM}$ BHBA resulted in a $21 \%$ decrease of AMPK- $\alpha$ phosphorylation after $2 \mathrm{~h}$, whereas after $4 \mathrm{~h}$ AMPK phosphorylation significantly increased by $132 \%$ when compared with $t=0$ (Fig. 1A; for each time $n=4-8)$. After 1,6 and $8 \mathrm{~h}$, AMPK- $\alpha$ phosphorylation was not changed when compared with $t=$ 0 (data not shown). In addition, GT1-7 cells treated with only 1.5 and $3 \mathrm{mM}$ BHBA revealed a significant decrease in AMPK phosphorylation after $2 \mathrm{~h}$, but after $4 \mathrm{~h}$ AMPK phosphorylation did not differ in comparison with $t=0$ (Fig. 1A). In addition, the loading control with $\beta$-tubulin revealed no differences between time points.

As BHBA is primarily used by the brain when glucose is reduced (Lindsay \& Setchell 1976, Arakawa et al. 1991), we next studied the effect of BHBA on AMPK- $\alpha$ phosphorylation in a lower $(5.5 \mathrm{mM})$ glucose-containing medium, which is more physiological (see also section on BHBA and glucose concentrations). In contrast to the results described in Fig. 1A, incubation with 1.5 and $3 \mathrm{mM} \mathrm{BHBA}$ for 2 and $4 \mathrm{~h}$, respectively, revealed that treatment with $3 \mathrm{mM}$ BHBA resulted in a $42 \%$ decrease of AMPK- $\alpha$ phosphorylation after $4 \mathrm{~h}$, whereas $1.5 \mathrm{mM}$ BHBA had no effect on AMPK- $\alpha$ phosphorylation (Fig. 1B; for each time $n=5-11$ ). The use of $6 \mathrm{mM}$ BHBA, however, resulted in a $35 \%$ decrease of AMPK- $\alpha$ phosphorylation after $4 \mathrm{~h}$. These results demonstrate that $6 \mathrm{mM}$ BHBA induced a significant $(P<0 \cdot 05)$ alteration of AMPK- $\alpha$ phosphorylation after 2 and $4 \mathrm{~h}$. Hence, we used $6 \mathrm{mM} \mathrm{BHBA}$ in the following experiments.

In $25 \mathrm{mM}$ glucose-containing medium, phosphorylation (inhibition) of the downstream target of AMPK, mTOR, at $\mathrm{Ser}^{2448}$ significantly increased to $129 \%$ after $2 \mathrm{~h}$ when incubated with $6 \mathrm{mM}$ BHBA (Fig. 2A; for each time $n=6-8$ ). After $4 \mathrm{~h}, \mathrm{mTOR}$ phosphorylation did not differ compared with $t=0 \quad(P=0 \cdot 1)$. In contrast, in $5.5 \mathrm{mM}$ glucosecontaining medium, phosphorylation of mTOR did not change upon BHBA stimulus (Fig. 2C; for each time $n=5$ ).

\section{Role of MCT1 for BHBA-induced AMPK phosphorylation}

The uptake of BHBA into cells might be mediated by the MCT1 system and its presence has recently been confirmed in hypothalamic neurons (Ainscow et al. 2002, Morris \& Felmlee 2008). Thus, we examined whether BHBA influences the expression of MCT1. We found that in $25 \mathrm{mM}$ glucose- 

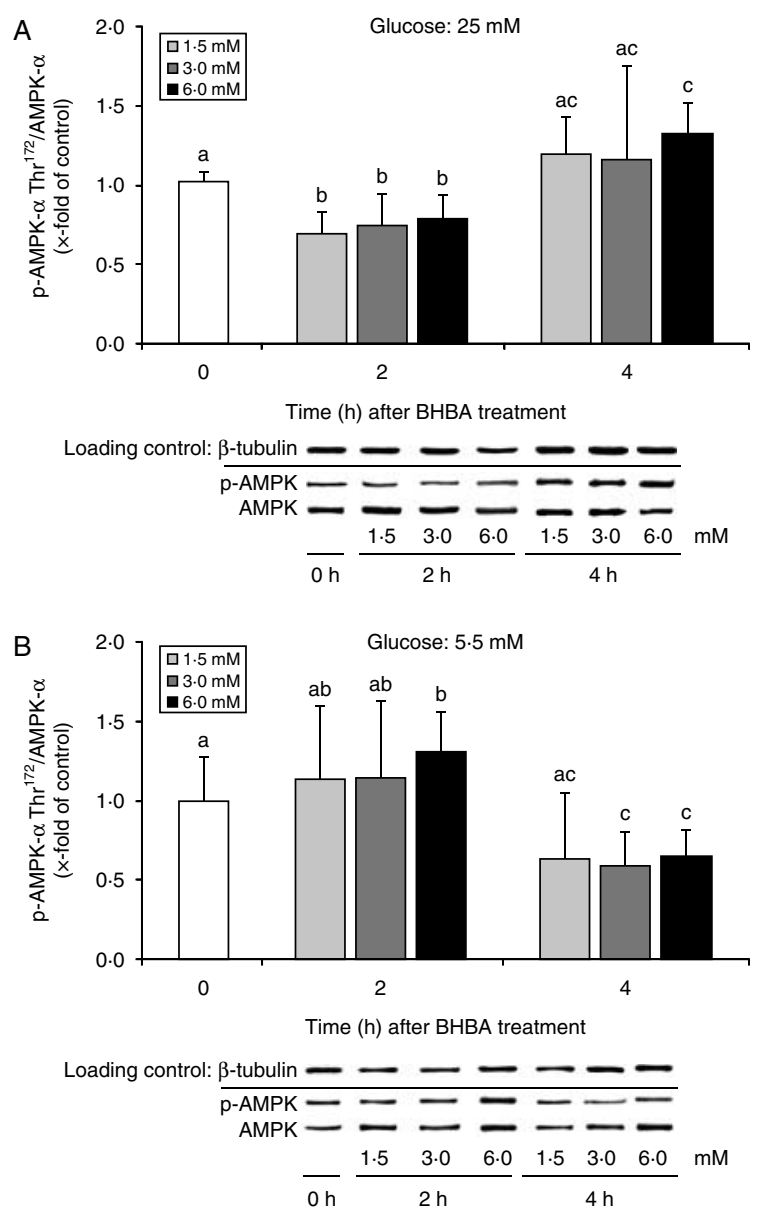

Figure 1 Effect of BHBA on AMPK in hypothalamic GT1-7 cells. GT1-7 cells maintained in (A) $25 \mathrm{mM}$ or (B) $5.5 \mathrm{mM}$ glucosecontaining medium were stimulated with or without BHBA in concentrations as indicated for 2 and $4 \mathrm{~h}$. Cell lysates were examined by western blot analysis with AMPK- $\alpha$ and phosphospecific AMPK- $\alpha$ Thr $^{172}$ antibodies. The densitometric ratio of pAMPK/AMPK was calculated against the ratio of untreated controls and is presented as mean \pm s.D. (for each time $n_{25}=4-8$ and $n_{5.5}=5-11$ ). The $\beta$-tubulin blot served as loading control. Mean values with different lowercase letters differ with $P<0 \cdot 05$ (Tukey's test; ANOVA: $\left.P<0 \cdot 05, F_{\mathrm{A}}=3 \cdot 8, F_{\mathrm{B}}=2 \cdot 0\right)$. A representative blot is shown below the graphs.

containing medium, $6 \mathrm{mM}$ BHBA significantly increased MCT1 expression after 2-4 h, suggesting an elevated intracellular uptake of BHBA (Fig. 2B; for each time $n=6-$ 8). Under conditions of $5 \cdot 5 \mathrm{mM}$ glucose, however, BHBA did not alter Mct 1 expression (Fig. 2D; for each time $n=5$ ).

To explore whether AMPK phosphorylation depends on MCT1, GT1-7 cells grown in $25 \mathrm{mM}$ glucose were preincubated with the MCT1 inhibitor pHMB $(1 \mu \mathrm{M})$ and subsequently stimulated with BHBA $(6 \mathrm{mM})$ for $4 \mathrm{~h}$. Figure $3 \mathrm{~A}$ shows that inhibition of MCT1 significantly reduced (but not fully suppressed) BHBA-induced phosphorylation of AMPK- $\alpha$ (Fig. $3 \mathrm{~A}$; for each time $n=5-6$ ). Interestingly, $\mathrm{pHMB}$ alone also stimulated AMPK- $\alpha$ phosphorylation (Fig. 3A).
The effect of BHBA on AMPK phosphorylation was abolished when cells were preincubated with the specific AMPK inhibitor Cpd C (10 $\mu$ M; Fig. 3A).

In low-glucose medium $(5.5 \mathrm{mM})$, diminished AMPK- $\alpha$ phosphorylation elicited by BHBA was prevented by either blockade of MCT1 or AMPK respectively (Fig. 3B; for each time $n=5)$. These results suggest that intracellular BHBA uptake mediated by MCT1 may trigger AMPK signalling.

\section{BHBA increases $\mathrm{Ca}^{2+}$ efflux in GT1-7 cells}

As the $\mathrm{Ca}^{2+} / \mathrm{CAMK}$ and the $\mathrm{Ca}^{2+} / \mathrm{CAMK}$ kinase (CAMKK (CAMKK2)) act as upstream signals for the phosphorylation of AMPK- $\alpha$ at $\mathrm{Thr}^{172}$ (Hawley et al. 2005, Hurley et al. 2005), we evaluated the effect of BHBA on intracellular $\left[\mathrm{Ca}^{2+}\right]_{i}$. Our results reveal that treatment with $6 \mathrm{mM}$ BHBA in $25 \mathrm{mM}$ glucose led to a rapid $\left[\mathrm{Ca}^{2+}\right]_{i}$ increase, as demonstrated by the increased intracellular Fluo-4 fluorescence (Fig. 4A and C). The onset of $\left[\mathrm{Ca}^{2+}\right]_{i}$ induced with $2 \mathrm{mM}$ BHBA occurred at a later time, to a lower extent, and was sustained for a shorter period of time compared with the $6 \mathrm{mM}$ BHBA stimulus (Fig. 4A; $n=5$ ). Under conditions of $5.5 \mathrm{mM}$ glucose, however, we only found a marginal $\left[\mathrm{Ca}^{2+}\right]_{i}$ increase after treatment with $6 \mathrm{mM}$ but not with $2 \mathrm{mM}$ BHBA (Fig. 4B; $n=4$ ).

\section{Regulation of Agrp $m R N A$ expression by BHBA under different glucose concentration}

AMPK is known to control food intake by regulating the expression of orexigenic and anorexigenic NP in the hypothalamus (Minokoshi et al. 2004, Shimizu et al. 2008). Therefore, we next investigated the impact of BHBA on orexigenic Agrp expression. In $25 \mathrm{mM}$ glucose, we found that transcripts of orexigenic Agrp relative to Gapdh were significantly increased after 4 and $7 \mathrm{~h}$ incubation with $6 \mathrm{mM}$ BHBA (Fig. 5A; for each time $n=5-12$ ). As AMPK phosphorylation and Agrp expression were highest after $4 \mathrm{~h}$, subsequent blocking experiments were performed for this time only. Blockade of AMPK by Cpd C $(10 \mu \mathrm{M})$ significantly decreased BHBA-induced Agrp expression (Fig. 5A), indicating that BHBA elicits orexigenic signalling specifically via AMPK. Furthermore, treatment with the MCT1 inhibitor pHMB $(1 \mu \mathrm{M})$ did not affect BHBA-mediated Agrp expression (Fig. 5A), suggesting that BHBA may either enter the cells by bypassing MCT1 or it binds to a BHBA membrane receptor without entering the cells. Regardless, our results demonstrate that BHBA activates the AMPK $\rightarrow$ AGRP pathway under conditions of $25 \mathrm{mM}$ glucose.

By contrast, cells incubated in $5.5 \mathrm{mM}$ glucose responded with decreased (42-46\%) Agrp mRNA expression after 4 and $7 \mathrm{~h}$ of BHBA treatment (Fig. 5B; for each time $n=7-13$ ), indicating that the ratio between BHBA and glucose determines feed intake-related signalling. This reduction could be prevented by pre-incubation with $\mathrm{Cpd} C$, indicating that $\mathrm{BHBA}$ diminishes orexigenic signalling via AMPK under 

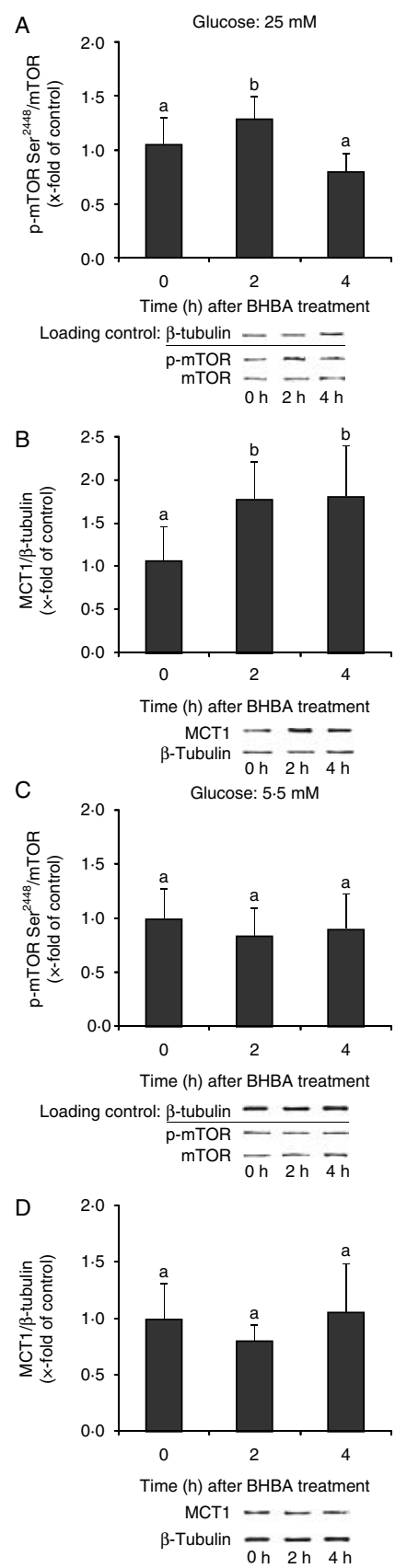

Figure 2 Effect of BHBA on mTOR and MCT1 in hypothalamic GT1-7 cells. GT1-7 cells cultured in $25 \mathrm{mM}$ (A and B) or $5.5 \mathrm{mM}$ (C and D) glucose were stimulated with or without BHBA $(6 \mathrm{mM})$. Cell lysates were probed with (A and C) antibodies against Ser ${ }^{2448}$ mTOR and total mTOR or with (B and D) antibodies against MCT1 and $\beta$-tubulin. The densitometric ratio of $\mathrm{pmTOR} / \mathrm{mTOR}$ and MCT1/ $\beta$-tubulin, respectively, was calculated. The ratio between BHBA-treated and -untreated controls is presented as mean \pm s.D. (for each time $n_{25}=6-8$ and $n_{5 \cdot 5}=5$ ). Mean values with different lowercase letters differ with $P<0.05$ (Tukey's test; ANOVA: $\left.P<0.05, F_{\mathrm{A}}=3 \cdot 4, F_{\mathrm{B}}=6.5, F_{\mathrm{C}}=0.4, F_{\mathrm{D}}=0.5\right)$. A representative blot is shown below the graphs. low-glucose conditions. In contrast to the result described for Fig. 5A, pHMB also prevented the reduction of BHBAinduced Agrp mRNA expression (Fig. 5B). Again, these results demonstrate that BHBA is a trigger for the AMPK $\rightarrow$ AGRP pathway but whether it increases or decreases orexigenic signalling depends on glucose concentration.

\section{Discussion}

\section{$B H B A$ and glucose concentrations}

Under normoglycaemic conditions, ketone bodies may occur in substantial concentrations $(\sim 0.5 \mathrm{mM})$ in humans (Laffel 1999). In ruminants, BHBA plasma concentration is even higher during and after food intake due to oxidation of ruminal butyrate in ruminal epithelial cells (van Soest 1994, Duske et al. 2009). During times of high energy demands, such as pregnancy, lactation, exercise and fasting, glucose becomes less available and energy stores are mobilised from body fat, and ketone bodies become an important respiratory fuel (Hawkins \& Biebuyck 1979). Thus, fasting may increase blood BHBA levels by 5-8 mM (Lindsay \& Setchell 1976, Cahill \& Veech 2003). In adult humans with diabetic ketoacidosis, circulating BHBA may even reach 3-14 mM while glucose is about $26 \mathrm{mM}$ (Friedman \& Ramirez 1994, Sheikh-Ali et al. 2008). In humans as well as in ruminants, circulating BHBA is also elevated in response to chronic consumption of a ketogenic diet (Brehm et al. 2003, Boden et al. 2005, Duske et al. 2009). Because of the relatively high fat and low carbohydrate content in rodent milk (mouse: $17-30 \%$ fat, $1-2 \%$ carbohydrates), BHBA is touted as one of the most important energy sources of suckling rodents (Hawkins et al. 1971, Görs et al. 2009). Thus, it is seems that among species (gastric, hind-gut or reticulorumen fermenters) and their developmental stages, a different hypothalamic sensitivity to BHBA exists. The similarity between all species, however, is that the mammalian brain can use BHBA instead of glucose primarily under hypoglycaemic conditions and that the extent of usage depends on the physiological state (Owen et al. 1967, Lindsay \& Setchell 1976, Laeger et al. 2010).

The extracellular glucose concentration in the brain is about $25 \%$ of the circulating glucose and varies between different brain areas and physiological states (Silver \& Erecinska 1994, de Vries et al. 2003). Under hyperglycaemic conditions, the extracellular glucose level in the brain may reach $>10 \cdot 5 \mathrm{mM}$ (Silver \& Erecinska 1994), while it is about $1.4 \mathrm{mM}$ in fed rats and $0.7 \mathrm{mM}$ in overnight-fasted rats (de Vries et al. 2003). Thus, the $25 \mathrm{mM}$ glucose concentration used in our in vitro study seems to correspond to about $100 \mathrm{mM}$ plasma glucose, which appears to be pathophysiological. This raises the question about the physiological relevance of our cell culture approach. However, because of the different metabolic rate and the diffusion-controlled availability of nutrients, for example, the glucose concentration determined in vivo could 

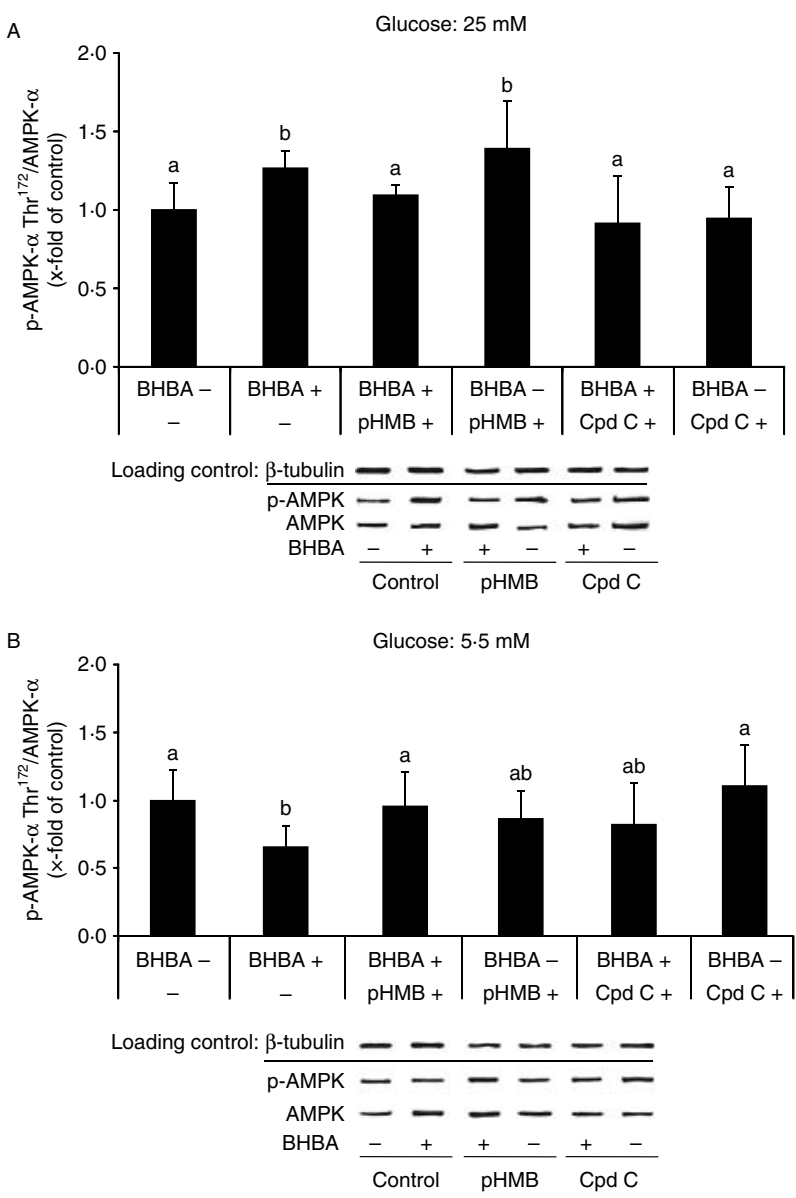

Figure 3 Effect of BHBA on AMPK in hypothalamic GT1-7 cells. GT1-7 cells kept in (A) $25 \mathrm{mM}$ or (B) $5.5 \mathrm{mM}$ glucose were preincubated with either $1 \mu \mathrm{M}$ of the MCT1 inhibitor pHMB or with $10 \mu \mathrm{M}$ of the AMPK inhibitor Cpd C, each for 5 min followed by the incubation with or without $6 \mathrm{mM}$ BHBA for $4 \mathrm{~h}$. Cell lysates were examined by western blot analysis with phospho-specific AMPK- $\alpha$ Thr $^{172}$ and normalised against total AMPK- $\alpha$. The densitometric ratio of $\mathrm{pAMPK/AMPK}$ was determined. Data are calculated as fold change of untreated controls and are presented as mean \pm s.D. (for each time $n_{25}=5-6$ and $n_{5 \cdot 5}=5$ ). Mean values with different lowercase letters differ with $P<0 \cdot 05$ (Tukey's test; ANOVA: $P<0 \cdot 05, F_{\mathrm{A}}=4 \cdot 5, F_{\mathrm{B}}=3 \cdot 2$ ). A representative blot is shown below the graphs.

not be simply applied to the cell culture. GT1-7 cells were generated via tumourigenesis (Mellon et al. 1990) and possess a approximately ten times higher glucose uptake and glycolysis rate compared with non-oncogenic cells (Dang \& Semenza 1999). Considering this fact, 25 and $5.5 \mathrm{mM}$ glucose used in cell culture would correspond to 2.5 and $0.55 \mathrm{mM}$ of extracellular glucose available for non-oncogenic cells, which in turn reflects the glucose concentration as measured in the brain (Silver \& Erecinska 1994). Moreover, a number of recent investigations (Lee et al. 2005, Li et al. 2006, Coyral-Castel et al. 2008, Wen et al. 2010, Hayes et al. 2011) also used glucose concentrations between 5.5 and $25 \mathrm{mM}$ for
GT1-7 cells, making our results comparable with these studies, while the use of $<5.5 \mathrm{mM}$ glucose led to cell death (Honegger et al. 2002).

One might assume that differences also exist between circulating and extracellular BHBA concentrations in the brain, but currently there are no data about it. However, further studies in whole animals are required to determine extracellular BHBA brain concentrations under various physiological conditions. Those data would help to examine, in a physiologically relevant range, which concentrations in the brain are to be adjusted in in vivo experiments to provoke alterations in feed intake signalling and in feed intake. When, however, the glucose/BHBA ratio (see below) instead of the absolute metabolite concentration is considered, our cell culture model mimics the in vivo situation and allows the investigation on principle signalling pathways induced by BHBA.

\section{BHBA uptake via MCT1}

Investigations on dissociated brain cells of rats revealed two forms of neuronal BHBA uptake: diffusion and carriermediated transport systems (Tildon \& Roeder 1988). Members of the $\mathrm{H}^{+}$-coupled MCT (SLC16A1) family (MCT1, MCT2 (SLC16A7) and MCT4; Morris \& Felmlee 2008) and members of the solute carrier (SLC) group, the sodium-coupled MCT1 (SMCT1; SLC5A8), have been identified as neuron-specific transporters for BHBA (Martin et al. 2006). MCT1 is abundantly distributed throughout the brain with high levels in the hypothalamic region and adjusted to the local glucose transporter GLUT1 (SLC2A1; Maurer et al. 2004). In our study, we demonstrated significantly increased MCT1 expression by $4 \mathrm{~h}$ of BHBA incubation in $25 \mathrm{mM}$ glucose-containing medium. However, to date, detailed mechanisms of transcriptional regulation of MCT1 expression by BHBA are not known. In addition, inhibition of MCT1 via $1 \mu \mathrm{M}$ pHMB suppresses (but not fully prevents) BHBA-induced AMPK phosphorylation in $25 \mathrm{mM}$ glucose and AMPK dephosphorylation in $5.5 \mathrm{mM}$ glucose respectively. Higher concentrations of pHMB (1 mM), however, did not lead to a further MCT1 blocking effect but rather to cell death (data not provided). Furthermore, we have shown that in $25 \mathrm{mM}$ glucose-containing medium, pHMB stimulates AMPK phosphorylation in the absence of BHBA, because the entrance of other metabolites (fuels) transported by MCT1, such as lactate, pyruvate, acetate and acetoacetate, is also blocked, which would thus lead to an increase in AMPK phosphorylation. Moreover, although pHMB suppresses AMPK phosphorylation in the presence of BHBA, it did not prevent increases in Agrp expression in $25 \mathrm{mM}$ glucose. These results suggest that BHBA triggers Agrp expression not exclusively via MCT1. For example, BHBA could affect intracellular signalling without entering the cell by binding to the membrane G protein-coupled receptor 109A (GPR109A (NIACR1)), which has been shown to be expressed in several portions of the brain in multiple species (Titgemeyer et al. 2011). 

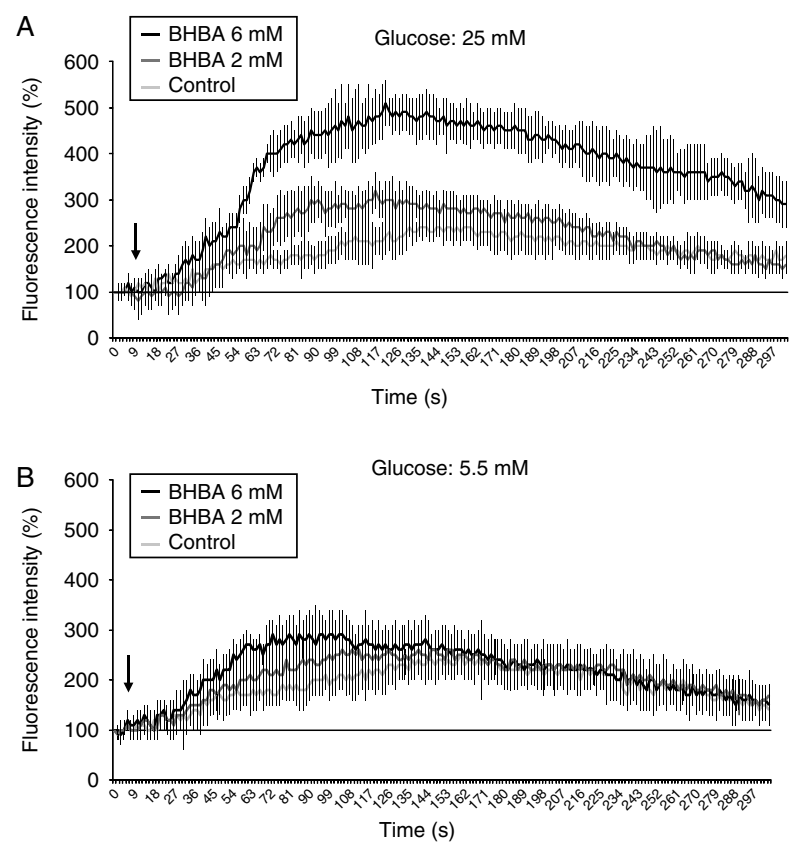

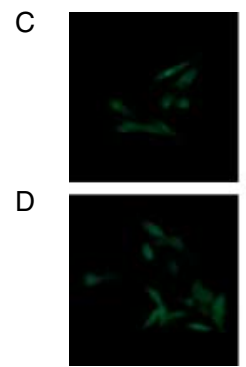

$0 \mathrm{~s}$
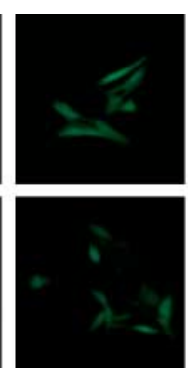

$100 \mathrm{~s}$

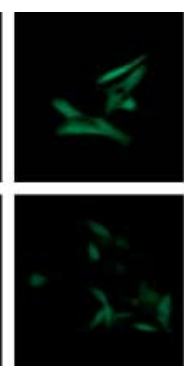

$200 \mathrm{~s}$

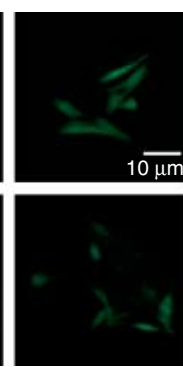

$300 \mathrm{~s}$
Figure 4 BHBA increases $\left[\mathrm{Ca}^{2+}\right]_{i}$ in GT1-7 cells cultured in (A) 25 and (B) $5.5 \mathrm{mM}$ glucose-containing DMEM. After stimulation with BHBA (2 and $6 \mathrm{mM}$ ), changes of the intracellular Fluo-4 fluorescence were recorded by confocal laser-scanning microscopy (C, e.g. in $25 \mathrm{mM}$ glucose). Control incubations were performed with water (D). The fluorescence intensity after application of BHBA or water (indicated by an arrow), respectively, was recorded in five (25 mM glucose) and four ( $5.5 \mathrm{mM}$ glucose) independent experiments each with seven to ten cells. Data are presented as mean \pm s.D. Significant differences $(P<0 \cdot 05$; ANOVA) in $25 \mathrm{mM}$ glucose between the control and the $6 \mathrm{mM}$ BHBA group occur $>50 \mathrm{~s}$ after application and between the control and the $2 \mathrm{mM}$ BHBA group $>64$ and $<96 \mathrm{~s}$. Significant differences in $5.5 \mathrm{mM}$ glucose between the control and the $6 \mathrm{mM}$ but not the $2 \mathrm{mM}$ BHBA treatment occurred $>50$ and $<100 \mathrm{~s}$ after application.

The latter assumption is supported by the finding that under conditions of $5.5 \mathrm{mM}$ glucose, BHBA indeed reduced AMPK phosphorylation but did not alter MCT1 expression. Thus, under low-glucose conditions, cells seem to dispense for the regulation of MCT1 expression, enabling BHBA to enter the cells particularly via a non-MCT1 mediated pathway. In this case, supraphysiological BHBA is not required for an increase in MCT1 expression.
Effect of BHBA on AMPK signalling

We have demonstrated that in the presence of $25 \mathrm{mM}$ glucose, BHBA increases MCT1 expression, which should support the uptake of BHBA into cells for altering AMPK activity. Our results demonstrate that treatment with $1 \cdot 5,3$ and $6 \mathrm{mM}$ BHBA led to a decline of AMPK- $\alpha$ phosphorylation after $2 \mathrm{~h}$. This means that hypothalamic cells are capable of responding to BHBA by decreasing its AMPK phosphorylation, which is in accordance with elevated ATP levels found in primary neurons incubated for $2 \mathrm{~h}$ with $20 \mathrm{mM}$ BHBA (in $10 \mathrm{mM}$ glucose-containing medium; Arakawa et al. 1991). Unfortunately, the authors did not show how the ATP level changed after $4 \mathrm{~h}$ of BHBA incubation. However, this temporally raised ATP level might be the reason for the diminished AMPK- $\alpha$ phosphorylation as observed in our study $2 \mathrm{~h}$ after BHBA treatment. In contrast, after $4 \mathrm{~h}$ of BHBA incubation, AMPK phosphorylation was increased. The stimulation of the AMPK pathway might be caused by a reduced glucose uptake as prolonged exposure to BHBA leads to a reduced glucose uptake, as demonstrated for cardiomyocytes (Pelletier \& Coderre 2007). Such a reduced glucose uptake (see also section on The glucose/BHBA ratio and food intake) potentially associated with reduced glucose oxidation would decrease the ATP level and thereby increase AMPK phosphorylation.

Studies performed in $5.5 \mathrm{mM}$ glucose-containing medium, however, reveal that BHBA-induced AMPK- $\alpha$ phosphorylation is contrarily regulated compared with culture conditions in $25 \mathrm{mM}$ glucose. This might be due to lowered activity of $\mathrm{Ca}^{2+}$-dependent kinases (see below) located upstream of AMPK or due to the fact that BHBA under low-glucose conditions serves as a metabolite for ATP production and thus contributes to decreased AMPK phosphorylation.

Based on the fact that the loading control $\beta$-tubulin did not change between times, changes in the phosphorylation of AMPK- $\alpha$ is not the result of changes in total AMPK- $\alpha$. This is strengthened by another study with GT1-7 cells, which demonstrated that high glucose supplementation $(25 \mathrm{mM})$ suppresses AMPK- $\alpha$ phosphorylation without changes in the total AMPK- $\alpha$ levels (Lee et al. 2005).

\section{Effect of BHBA on $m$ TOR signalling}

One of the downstream targets of AMPK, mTOR, is a highly conserved serine/threonine kinase, integrating nutrient and hormonal signals to control growth and development (Bolster et al. 2002, Kimura et al. 2003). In the arcuate nucleus of the hypothalamus, mTOR is localised in POMC and AGRP/ NPY neurons that are involved in food intake regulation (Cota et al. 2006). Fasting induces a decrease in mTOR phosphorylation at $\mathrm{Ser}^{2448}$ (Cota et al. 2006). Our results demonstrate that BHBA increases phosphorylation of mTOR at $\operatorname{Ser}^{2448}$ after $2 \mathrm{~h}$, which inversely corresponds to a decline of p-AMPK. Conversely, reduced mTOR phosphorylation 

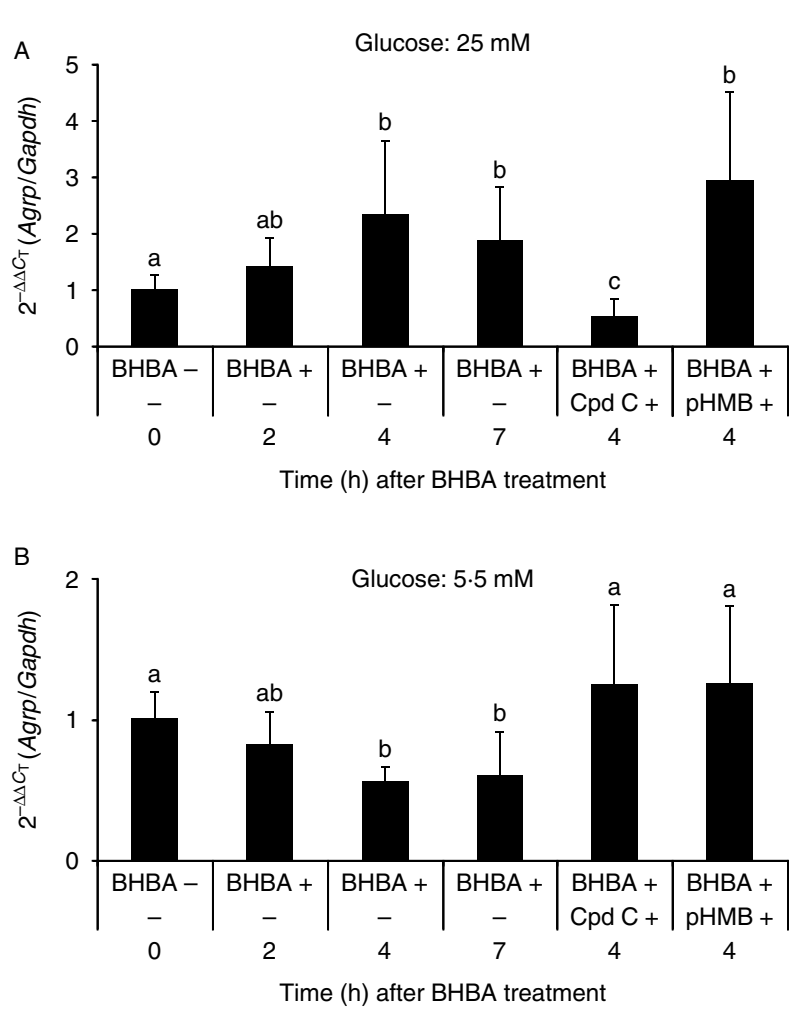

Figure 5 BHBA increases AMPK-mediated orexigenic Agrp expression in hypothalamic GT1-7 cells cultured in $25 \mathrm{mM}$ glucose-containing medium (A). In contrast, BHBA decreases Agrp expression in hypothalamic GT1-7 cells cultured in $5.5 \mathrm{mM}$ glucose-containing medium (B). GT1-7 cells were either stimulated with BHBA $(6 \mathrm{mM})$ alone or preincubated with $1 \mu \mathrm{M}$ of the MCT1 inhibitor pHMB or with $10 \mu \mathrm{M}$ of the AMPK inhibitor Cpd C, respectively, followed by BHBA $(6 \mathrm{mM})$ application. At times as indicated, transcript levels of Agrp and Gapdh were quantified by real-time PCR. $2^{-\Delta \Delta C_{\mathrm{T}}}$ method was used to analyse the relative gene expression. The graph represents means \pm s.D. originating from three independent experiments (for each time $n_{25}=5-12$ and $n_{5.5}=$ 7-13). Mean values with different lowercase letters differ with $P<0 \cdot 05$ (Tukey's test; ANOVA: $P<0 \cdot 05, F_{\mathrm{A}}=6 \cdot 3, F_{\mathrm{B}}=6 \cdot 3$ ).

after $4 \mathrm{~h}$ BHBA treatment is associated with significantly raised AMPK phosphorylation in a culture medium containing $25 \mathrm{mM}$ glucose. This inverse phosphorylation is in accordance with earlier findings in skeletal muscle cells and in $\mathrm{C} 2 \mathrm{C} 12$ myoblast cells, showing that AMPK negatively controls mTOR signalling (Bolster et al. 2002, Du et al. 2007). Why under culture conditions of $5.5 \mathrm{mM}$ glucose changes in mTOR phosphorylation (despite of observed p-AMPK changes) were not as pronounced as in $25 \mathrm{mM}$ glucose is currently unknown.

Effect of $B H B A$ on $\left[\mathrm{Ca}^{2+}\right]_{i}$

Besides the activation of AMPK by LKB1-AMP, $\mathrm{Ca}^{2+} /$ CAMKK may activate its downstream target CAMKI that in turn also phosphorylates AMPK- $\alpha$ at
$\mathrm{Thr}^{172}$ (Witters et al. 2006). Therefore, we investigated the effect of BHBA on intracellular $\left[\mathrm{Ca}^{2+}\right]_{i}$. Our results show that BHBA elicits a faster increase of $\left[\mathrm{Ca}^{2+}\right]_{i}$ compared with AMPK phosphorylation, suggesting that BHBA triggers the AMPK pathway via $\mathrm{Ca}^{2+}$-dependent signalling under conditions of $25 \mathrm{mM}$ glucose. In the presence of $5.5 \mathrm{mM}$ glucose, BHBA induces a only marginal $\left[\mathrm{Ca}^{2+}\right]_{i}$ influx, indicating that $\mathrm{Ca}^{2+}$-dependent kinases should not significantly phosphorylate AMPK under these conditions. On the other hand, a previous study revealed that $\left[\mathrm{Ca}^{2+}\right]_{i}$ raised via AMPK activation in hypothalamic neurons (Kohno et al. 2008). However, further studies, e.g. using calcium-binding agents, are required to determine the association between $\left[\mathrm{Ca}^{2+}\right]_{i}$ increase and AMPK signalling triggered by BHBA.

\section{Effect of BHBA on Agrp $m R N A$ expression}

Hypothalamic AMPK inhibition reduces Agrp expression (Shimizu et al. 2008) and induces a reduction of food intake (Minokoshi et al. 2004, Xue \& Kahn 2006). In contrast, increased activation of AMPK in the arcuate nucleus of the hypothalamus leads to an increased expression of Agrp (Shimizu et al. 2008). Consistent with these findings, we demonstrate that increased AMPK phosphorylation is accompanied with increased Agrp expression (25 mM glucose) and decreased AMPK phosphorylation is associated with decreased Agrp abundance (5.5 mM glucose). The alteration of Agrp expression is mediated via AMPK because Cpd C prevents BHBA-induced aberrant Agrp expression under both glucose conditions. Hence, our results demonstrate the existence of the BHBA $\rightarrow$ AMPK $\rightarrow$ AGRP pathway.

\section{The glucose/BHBA ratio and food intake}

Whether this pathway is activated or inhibited seems to depend on glucose concentration. In this study using tumorous cells, we were able to demonstrate that in a medium containing $25 \mathrm{mM}$ glucose, $6 \mathrm{mM}$ BHBA elicits increased expression of Agrp, whereas under culture conditions of $5.5 \mathrm{mM}$ glucose, Agrp expression was significantly reduced. Thus, we investigated glucose/BHBA ratio of $\sim 4: 1$ and $\sim 1: 1$ respectively. The high glucose/BHBA ratio used in our study might be comparable with high plasma glucose concentrations (glucose/BHBA ratio of $\sim 4: 1$ ) observed in patients with diabetic ketosis (Sheikh-Ali et al. 2008), a metabolic situation associated with hyperphagia (Toyonaga et al. 2002). Similarly, streptozotocin-treated rats are hyperglycaemic, ketoacidotic and hyperphagic (Goodman 1987, Friedman \& Ramirez 1994), although this might also be due to insulin deficiency. Moreover, consumption of highfat diets, which increase circulating glucose and BHBA concentrations, leads to increased meal size and greater energy intake in rodent and humans (Warwick 1996, Hu et al. 2004). Also, pregnant cows possessing higher plasma BHBA and glucose concentrations (glucose/BHBA ratio of $\sim 3: 1$ ) due to feeding a ketogenic diet show the higher feed intake 
compared with cows with lower plasma BHBA and glucose concentrations (Duske et al. 2009). Whether the increased feed intake in the situation of high glucose is due to or despite high BHBA remains to be investigated. However, the putative orexigenic characteristics of BHBA in the presence of high glucose could be explained by the fact that BHBA acts similar to 2-deoxyglucose as a glucose anti-metabolite, thereby inhibits glucose uptake and ATP production and may stimulate feed intake even at satiation (Minami et al. 1995).

BHBA treatment in the lower $(5 \cdot 5 \mathrm{mM})$ glucose (glucose/ BHBA ratio of $\sim 1: 1$ )-containing medium, on the other hand, reflects the metabolic situation present in normo- or hypoglycaemic animals receiving BHBA infusions. Thus, for example, i.c.v. application of BHBA suppresses food intake in the long term in Wistar King A (Sakata et al. 1982) and Osborne-Mendel rats (Arase et al. 1988). However, in the study of Davis et al. (1981), only a numeric reduction of food intake upon i.c.v. BHBA infusion could be observed when compared with saline-treated controls. Women eating a very low-carbohydrate diet reveal significantly increased BHBA and normal glucose levels whereby food intake spontaneously decreased (Brehm et al. 2003). Additionally, early lactating cows with reduced glucose but elevated BHBA levels (glucose/BHBA ratio of 1:1) ate less than non-ketotic cows with a 4:1 ratio (Hammon et al. 2009). Thus, the majority of these studies indicate that BHBA exerts an anorexigenic role in the brain (in normo- or hypoglycaemia), and our results obtained from the studies in $5.5 \mathrm{mM}$ glucose (glucose/BHBA ratio of 1:1) demonstrates that this may be due to reduced AMPK phosphorylation and reduced Agrp expression. The anorexic BHBA trait might be caused by the observation that BHBA serves under normal or lowered glucose condition as metabolite for ATP production and thus trigger for diminished Agrp expression. This mechanism would explain earlier findings, showing that the metabolic conversion of BHBA by the brain occurs primarily under hypoglycaemic conditions (Ruderman et al. 1974, Lindsay \& Setchell 1976).

However, although the cell culture model used requires glucose and BHBA concentrations above those existing in vivo, the glucose/BHBA ratio investigated herein is highly comparable with the in vivo situation. Considering this fact, we propose a cellular pathway, which integrates BHBA in the control of food intake. Nevertheless, further cell and in vivo studies are necessary to confirm our current results by which BHBA regulates Agrp expression in dependency of the glucose level.

\section{Conclusions}

To summarise, we investigated a cellular pathway triggered in response to BHBA and provide new knowledge about BHBA's possible impact on food intake regulation. We have demonstrated that BHBA is capable of entering the cell not only via MCT1 but also via other routes with subsequent mobilisation of calcium. Furthermore, BHBA modulates
AMPK- $\alpha$ phosphorylation. Associated with an increased AMPK phosphorylation, Agrp mRNA expression increases after $4 \mathrm{~h}$ of BHBA treatment in a $25 \mathrm{mM}$ glucose-containing medium. However, although in vitro conditions for GT1-7 cells require higher glucose concentrations, it is uncertain whether $25 \mathrm{mM}$ glucose reflects any physiological relevance for in vivo comparisons. In the presence of $5.5 \mathrm{mM}$ glucose, however, BHBA mobilises intracellular $\mathrm{Ca}^{2+}$ to a much lower extent and reduces AMPK phosphorylation and Agrp expression after $4 \mathrm{~h}$. The latter cellular signal transduction mechanism may contribute to the understanding of the feed intake depressive effect of BHBA observed after in vivo infusions.

\section{Declaration of interest}

The authors declare that there is no conflict of interest that could be perceived as prejudicing the impartiality of the research reported.

\section{Funding}

This research did not receive any specific grant from any funding agency in the public, commercial or not-for-profit sector.

\section{Acknowledgements}

The authors thank Claudia Arlt, Claudia Reiko (FBN) and Sebastian Bühler (University of Rostock) for their skillful assistance and excellent technical support.

\section{References}

Ainscow EK, Mirshamsi S, Tang T, Ashford ML \& Rutter GA 2002 Dynamic imaging of free cytosolic ATP concentration during fuel sensing by rat hypothalamic neurones: evidence for ATP-independent control of ATP-sensitive $\mathrm{K}(+)$ channels. Journal of Physiology 544 429-445. (doi:10.1113/jphysiol.2002.022434)

Arakawa T, Goto T \& Okada Y 1991 Effect of ketone body (D-3hydroxybutyrate) on neural activity and energy metabolism in hippocampal slices of the adult guinea pig. Neuroscience Letters 130 53-56. (doi:10.1016/ 0304-3940(91)90225-I)

Arase K, Fisler JS, Shargill NS, York DA \& Bray GA 1988 Intracerebroventricular infusions of 3-OHB and insulin in a rat model of dietary obesity. American Journal of Physiology 255 R974-R981.

Boden G, Sargrad K, Homko C, Mozzoli M \& Stein TP 2005 Effect of a lowcarbohydrate diet on appetite, blood glucose levels, and insulin resistance in obese patients with type 2 diabetes. Annals of Internal Medicine 142 403-411.

Bolster DR, Crozier SJ, Kimball SR \& Jefferson LS 2002 AMP-activated protein kinase suppresses protein synthesis in rat skeletal muscle through down-regulated mammalian target of rapamycin (mTOR) signaling. Journal of Biological Chemistry 277 23977-23980. (doi:10.1074/jbc. C200171200)

Brehm BJ, Seeley RJ, Daniels SR \& D'Alessio DA 2003 A randomized trial comparing a very low carbohydrate diet and a calorie-restricted low fat diet on body weight and cardiovascular risk factors in healthy women. Journal of Clinical Endocrinology and Metabolism 88 1617-1623. (doi:10.1210/jc.2002021480)

Cahill GF Jr \& Veech RL 2003 Ketoacids? Good medicine? Transactions of the American Clinical and Climatological Association 114 149-161. 
Cota D, Proulx K, Smith KA, Kozma SC, Thomas G, Woods SC \& Seeley RJ 2006 Hypothalamic mTOR signaling regulates food intake. Science $\mathbf{3 1 2}$ 927-930. (doi:10.1126/science.1124147)

Coyral-Castel S, Tosca L, Ferreira G, Jeanpierre E, Rame C, Lomet D, Caraty A, Monget P, Chabrolle C \& Dupont J 2008 The effect of AMP-activated kinase activation on gonadotrophin-releasing hormone secretion in GT1-7 cells and its potential role in hypothalamic regulation of the oestrous cyclicity in rats. Journal of Neuroendocrinology 20 335-346. (doi:10.1111/j.1365-2826.2007.01643.x)

Dang CV \& Semenza GL 1999 Oncogenic alterations of metabolism. Trends in Biochemical Sciences 24 68-72. (doi:10.1016/S0968-0004(98)01344-9)

Davis JD, Wirtshafter D, Asin KE \& Brief D 1981 Sustained intracerebroventricular infusion of brain fuels reduces body-weight and food-intake in rats. Science 212 81-83. (doi:10.1126/science.7193909)

Deuticke B 1982 Monocarboxylate transport in erythrocytes. Journal of Membrane Biology 70 89-103. (doi:10.1007/BF01870219)

Du M, Shen QW, Zhu MJ \& Ford SP 2007 Leucine stimulates mammalian target of rapamycin signaling in $\mathrm{C} 2 \mathrm{C} 12$ myoblasts in part through inhibition of adenosine monophosphate-activated protein kinase. Journal of Animal Science 85 919-927. (doi:10.2527/jas.2006-342)

Duske K, Hammon HM, Langhof AK, Bellmann O, Losand B, Nürnberg K, Nürnberg G, Sauerwein H, Seyfert HM \& Metges CC 2009 Metabolism and lactation performance in dairy cows fed a diet containing rumenprotected fat during the last twelve weeks of gestation. Journal of Dairy Science 92 1670-1684. (doi:10.3168/jds.2008-1543)

Friedman MI \& Ramirez I 1994 Food intake in diabetic rats: relationship to metabolic effects of insulin treatment. Physiology \& Behavior 56 373-378. (doi:10.1016/0031-9384(94)90209-7)

Goodman MN 1987 Myofibrillar protein breakdown in skeletal muscle is diminished in rats with chronic streptozocin-induced diabetes. Diabetes $\mathbf{3 6}$ 100-105. (doi:10.2337/diabetes.36.1.100)

Görs S, Kucia M, Langhammer M, Junghans P \& Metges CC 2009 Technical note: milk composition in mice - methodological aspects and effects of mouse strain and lactation day. Journal of Dairy Science 92 632-637. (doi:10.3168/jds.2008-1563)

Hammon HM, Stürmer G, Schneider F, Tuchscherer A, Blum H, Engelhard T, Genzel A, Staufenbiel R \& Kanitz W 2009 Performance and metabolic and endocrine changes with emphasis on glucose metabolism in high-yielding dairy cows with high and low fat content in liver after calving. Journal of Dairy Science 92 1554-1566. (doi:10.3168/jds.2008-1634)

Hardie DG, Salt IP, Hawley SA \& Davies SP 1999 AMP-activated protein kinase: an ultrasensitive system for monitoring cellular energy charge. Biochemical Journal 338 717-722. (doi:10.1042/0264-6021:3380717)

Hawkins RA \& Biebuyck JF 1979 Ketone bodies are selectively used by individual brain regions. Science 205 325-327. (doi:10.1126/science. 451608)

Hawkins RA, Williamson DH \& Krebs HA 1971 Ketone-body utilization by adult and suckling rat brain in vivo. Biochemical Journal 122 13-18.

Hawley SA, Boudeau J, Reid JL, Mustard KJ, Udd L, Makela TP, Alessi DR \& Hardie DG 2003 Complexes between the LKB1 tumor suppressor, STRAD alpha/beta and MO25 alpha/beta are upstream kinases in the AMP-activated protein kinase cascade. Journal of Biology 2 28. (doi:10.1186/ 1475-4924-2-28)

Hawley SA, Pan DA, Mustard KJ, Ross L, Bain J, Edelman AM, Frenguelli BG \& Hardie DG 2005 Calmodulin-dependent protein kinase kinase-beta is an alternative upstream kinase for AMP-activated protein kinase. Cell Metabolism 2 9-19. (doi:10.1016/j.cmet.2005.05.009)

Hayes MR, Leichner TM, Zhao S, Lee GS, Chowansky A, Zimmer D, De Jonghe BC, Kanoski SE, Grill HJ \& Bence KK 2011 Intracellular signals mediating the food intake-suppressive effects of hindbrain glucagon-like peptide-1 receptor activation. Cell Metabolism 13 320-330. (doi:10.1016/j. cmet.2011.02.001)

Honegger P, Braissant O, Henry H, Boulat O, Bachmann C, Zurich MG \& Pardo B 2002 Alteration of amino acid metabolism in neuronal aggregate cultures exposed to hypoglycaemic conditions. Journal of Neurochemistry $\mathbf{8 1}$ 1141-1151. (doi:10.1046/j.1471-4159.2002.00888.x)
Hu CC, Qing K \& Chen Y 2004 Diet-induced changes in stearoyl-CoA desaturase 1 expression in obesity-prone and -resistant mice. Obesity Research 12 1264-1270. (doi:10.1038/oby.2004.160)

Hurley RL, Anderson KA, Franzone JM, Kemp BE, Means AR \& Witters LA $2005 \mathrm{The}^{2+}{ }^{2+} /$ calmodulin-dependent protein kinase kinases are AMP-activated protein kinase kinases. Journal of Biological Chemistry 280 29060-29066. (doi:10.1074/jbc.M503824200)

Iwasaki Y, Nishiyama M, Taguchi T, Kambayashi M, Asai M, Yoshida M, Nigawara T \& Hashimoto K 2007 Activation of AMP-activated protein kinase stimulates proopiomelanocortin gene transcription in AtT20 corticotroph cells. American Journal of Physiology. Endocrinology and Metabolism 292 E1899-E1905. (doi:10.1152/ajpendo.00116.2006)

Kimura N, Tokunaga C, Dalal S, Richardson C, Yoshino K, Hara K, Kemp BE, Witters LA, Mimura O \& Yonezawa K 2003 A possible linkage between AMP-activated protein kinase (AMPK) and mammalian target of rapamycin (mTOR) signalling pathway. Genes to Cells: Devoted to Molecular E Cellular Mechanisms 8 65-79. (doi:10.1046/j.1365-2443.2003.00615.x)

Kohno D, Sone H, Minokoshi Y \& Yada T 2008 Ghrelin raises $\left[\mathrm{Ca}^{2+}\right.$ ]i via AMPK in hypothalamic arcuate nucleus NPY neurons. Biochemical and Biophysical Research Communications 366 388-392. (doi:10.1016/j.bbrc. 2007.11.166)

Kola B 2008 Role of AMP-activated protein kinase in the control of appetite. Journal of Neuroendocrinology 20 942-951. (doi:10.1111/j.1365-2826.2008. 01745.x)

Laeger T, Metges CC \& Kuhla B 2010 Role of beta-hydroxybutyric acid in the central regulation of energy balance. Appetite 54 450-455. (doi:10.1016/j.appet.2010.04.005)

Laffel L 1999 Ketone bodies: a review of physiology, pathophysiology and application of monitoring to diabetes. Diabetes/Metabolism Research and Reviews 15 412-426. (doi:10.1002/(SICI)1520-7560(199911/12)15:6< 412::AID-DMRR72>3.0.CO;2-8)

Lee K, Li B, Xi X, Suh Y \& Martin RJ 2005 Role of neuronal energy status in the regulation of adenosine $5^{\prime}$-monophosphate-activated protein kinase, orexigenic neuropeptides expression, and feeding behavior. Endocrinology 146 3-10. (doi:10.1210/en.2004-0968)

Li B, Lee K \& Martin RJ 2006 Overexpression of glucose transporter 2 in GT1-7 cells inhibits AMP-activated protein kinase and agouti-related peptide expression. Brain Research 1118 1-5. (doi:10.1016/j.brainres.2006. 08.032)

Lindsay DB \& Setchell BP 1976 The oxidation of glucose, ketone bodies and acetate by the brain of normal and ketonaemic sheep. Journal of Physiology 259 801-823.

Livak KJ \& Schmittgen TD 2001 Analysis of relative gene expression data using real-time quantitative PCR and the $2(-$ Delta Delta $C(T))$ method. Methods 25 402-408. (doi:10.1006/meth.2001.1262)

Martin PM, Gopal E, Ananth S, Zhuang L, Itagaki S, Prasad BM, Smith SB, Prasad PD \& Ganapathy V 2006 Identity of SMCT1 (SLC5A8) as a neuronspecific $\mathrm{Na}^{+}$-coupled transporter for active uptake of L-lactate and ketone bodies in the brain. Journal of Neurochemistry 98 279-288. (doi:10.1111/j. 1471-4159.2006.03878.x)

Maurer MH, Canis M, Kuschinsky W \& Duelli R 2004 Correlation between local monocarboxylate transporter 1 (MCT1) and glucose transporter 1 (GLUT1) densities in the adult rat brain. Neuroscience Letters 355 105-108. (doi:10.1016/j.neulet.2003.10.056)

Mellon PL, Windle JJ, Goldsmith PC, Padula CA, Roberts JL \& Weiner RI 1990 Immortalization of hypothalamic GnRH neurons by genetically targeted tumorigenesis. Neuron 5 1-10. (doi:10.1016/08966273(90)90028-E)

Minami S, Kamegai J, Sugihara H, Suzuki N, Higuchi H \& Wakabayashi I 1995 Central glucoprivation evoked by administration of 2-deoxy-Dglucose induces expression of the $c-f o s$ gene in a subpopulation of neuropeptide Y neurons in the rat hypothalamus. Brain Research. Molecular Brain Research 33 305-310. (doi:10.1016/0169-328X(95)00151-H)

Minokoshi Y, Alquier T, Furukawa N, Kim YB, Lee A, Xue B, Mu J, Foufelle F, Ferre P, Birnbaum MJ et al. 2004 AMP-kinase regulates food intake by responding to hormonal and nutrient signals in the hypothalamus. Nature 428 569-574. (doi:10.1038/nature02440) 
Morris ME \& Felmlee MA 2008 Overview of the proton-coupled MCT (SLC16A) family of transporters: characterization, function and role in the transport of the drug of abuse gamma-hydroxybutyric acid. AAPS Journal 10 311-321. (doi:10.1208/s12248-008-9035-6)

Morrison CD, Xi X, White CL, Ye J \& Martin RJ 2007 Amino acids inhibit Agrp gene expression via an mTOR-dependent mechanism. American Journal of Physiology. Endocrinology and Metabolism 293 E165-E171. (doi:10.1152/ajpendo.00675.2006)

Owen OE, Morgan AP, Kemp HG, Sullivan JM, Herrera MG \& Cahill GF 1967 Brain metabolism during fasting. Journal of Clinical Investigation 46 1589-1595. (doi:10.1172/JCI105650)

Pelletier A \& Coderre L 2007 Ketone bodies alter dinitrophenol-induced glucose uptake through AMPK inhibition and oxidative stress generation in adult cardiomyocytes. American Journal of Physiology. Endocrinology and Metabolism 292 E1325-E1332. (doi:10.1152/ajpendo.00186.2006)

Pöhland R, Tomek W, Becker F, Kurth J, Kanitz W \& Bhojwani S 2008 Qualitative and quantitative differences of cytoskeleton proteins in embryos produced in vitro, in vivo, and by somatic nuclear transfer. Molecular Reproduction and Development 75 1109-1119. (doi:10.1002/mrd.20848)

Ruderman NB, Ross PS, Berger M \& Goodman MN 1974 Regulation of glucose and ketone-body metabolism in brain of anaesthetized rats. Biochemical Journal 138 1-10.

Sakata T, Oomura Y, Tsutsui K, Fukushima M, Fujimoto K, Matsumoto I \& Uhara TK 1982 Hunger and satiety related activity induced by certain metabolites in rats. In The Neural Basis of Feeding and Reward, pp 339-354. Eds BG Hoebel \& D Novin. Brunswick (USA): Haer Institute for Electrophysiological Research

Sheikh-Ali M, Karon BS, Basu A, Kudva YC, Muller LA, Xu J, Schwenk WF \& Miles JM 2008 Can serum beta-hydroxybutyrate be used to diagnose diabetic ketoacidosis? Diabetes Care 31 643-647. (doi:10.2337/ dc07-1683)

Shimizu H, Arima H, Watanabe M, Goto M, Banno R, Sato I, Ozaki N, Nagasaki H \& Oiso Y 2008 Glucocorticoids increase neuropeptide Y and agouti-related peptide gene expression via adenosine monophosphateactivated protein kinase signaling in the arcuate nucleus of rats. Endocrinology 149 4544-4553. (doi:10.1210/en.2008-0229)

Silver IA \& Erecinska M 1994 Extracellular glucose concentration in mammalian brain: continuous monitoring of changes during increased neuronal activity and upon limitation in oxygen supply in normo-, hypo-, and hyperglycemic animals. Journal of Neuroscience 14 5068-5076.

van Soest PJ 1994 Intermediary metabolism. In Nutritional Ecology of the Ruminant, 2nd edn, pp 312-324. Ed. PJ van Soest. Ithaca and London: Cornell University Press.
Tildon JT \& Roeder LM 1988 Transport of 3-hydroxy[3-14C]butyrate by dissociated cells from rat brain. American Journal of Physiology 255 C133-C139.

Titgemeyer EC, Mamedova LK, Spivey KS, Farney JK \& Bradford BJ 2011 An unusual distribution of the niacin receptor in cattle. Journal of Dairy Science 94 4962-4967. (doi:10.3168/jds.2011-4193)

Toyonaga T, Kondo T, Miyamura N, Sekigami T, Sonoda K, Kodama S, Shirakami A, Shirotani T \& Araki E 2002 Sudden onset of diabetes with ketoacidosis in a patient treated with FK506/tacrolimus. Diabetes Research and Clinical Practice 56 13-18. (doi:10.1016/S0168-8227(01)00354-0)

de Vries MG, Arseneau LM, Lawson ME \& Beverly JL 2003 Extracellular glucose in rat ventromedial hypothalamus during acute and recurrent hypoglycemia. Diabetes 52 2767-2773. (doi:10.2337/diabetes.52.11.2767)

Warwick ZS 1996 Probing the causes of high-fat diet hyperphagia: a mechanistic and behavioral dissection. Neuroscience and Biobehavioral Reviews 20 155-161. (doi:10.1016/0149-7634(95)00034-C)

Wen JP, Liu CE, Hu YT, Chen G \& Lin LX 2010 Globular adiponectin regulates energy homeostasis through AMP-activated protein kinaseacetyl-CoA carboxylase (AMPK/ACC) pathway in the hypothalamus. Molecular and Cellular Biochemistry 344 109-115. (doi:10.1007/s11010010-0534-2)

Witters LA, Kemp BE \& Means AR 2006 Chutes and ladders: the search for protein kinases that act on AMPK. Trends in Biochemical Sciences 31 13-16. (doi:10.1016/j.tibs.2005.11.009)

Xue B \& Kahn BB 2006 AMPK integrates nutrient and hormonal signals to regulate food intake and energy balance through effects in the hypothalamus and peripheral tissues. Journal of Physiology 574 73-83. (doi:10.1113/jphysiol.2006.113217)

Yang Y, Zhou LB, Liu SQ, Tang JF, Li FY, Li RY, Song HD \& Chen MD 2005 Expression of feeding-related peptide receptors mRNA in GT1-7 cell line and roles of leptin and orexins in control of GnRH secretion. Acta Pharmacologica Sinica 26 976-981. (doi:10.1111/j.1745-7254.2005.00118.x)

Zhou G, Myers R, Li Y, Chen Y, Shen X, Fenyk-Melody J, Wu M, Ventre J, Doebber T, Fujii N et al. 2001 Role of AMP-activated protein kinase in mechanism of metformin action. Journal of Clinical Investigation 108 1167-1174. (doi:10.1172/JCI13505)

Received in final form 1 February 2012

Accepted 22 February 2012

Made available online as an Accepted Preprint 22 February 2012 